\title{
VIEDENSKÁ ARBITRÁŽ V DOBOVEJ SLOVENSKEJ POÉZIII A PIESŇACH
}

\author{
PETER TOLLAROVIČ
}

TOLLAROVIČ, Peter: Vienna Arbitration in Contemporary Slovak Poetry and Songs, 2019, Vol. 1, Issue 1, pp. 51 - 56. DOI: 10.17846/CEV.2019.01.1.51-56.

ABSTRACT: The study approximates authentic verbal work from the breaks of 1938/1939. During this period, the poets formed the difficult political events that hit Czechoslovakia, especially the territory of today's Slovakia. These events were written by the leading Slovak writers, whose poems were collected by Emil Boleslav Lukáč, but also by the lesser known authors who published separate poetry collections such as Anton Prídavok, Jozef M. Brodi and Lubomír Kupčok. The crimes committed by the Slovaks perceived the authors through the nation and individuals. These ideas are also captured in popular pop songs that were popular and broadcast on the radio.

KEYWORDS: Vienna Arbitration. Slovak Autonomy. Political Poetry. War Poetry.

Pre historikov je dnes tažké určit, ktorá z udalostí roku 1938 najviac zasiahla do prúdu dejín Slovenska a jeho obyvatelov. Príležitostná poézia súvisiaca s politicko-spoločenským dianím v našej vlasti našla v 20. storočí hojné uplatnenie. Tragédiu 1. svetovej vojny zachytil Pavol Országh Hviezdoslav vo svojich Krvavých sonetoch alebo Martin Rázus v zbierke To je vojna! Počas Prvej republiky zasa viacerí básnici vyjadrovali svoj negatívny postoj k nerovnocennému postaveniu Slovenska v rámci rodiacej sa modernej republiky. Za všetkých spomeňme aspoň Andreja Žarnova a jeho zbierku Stráž pri Morave (1925) z polovice 20. rokov.

Na sklonku roku 1938 sa naskytlo viacero zväčša negatívnych podnetov, ktoré sa stali inšpiráciou pre množstvo známych i menej známych slovenských básnikov. Možno konštatovat', že radostnú udalost', vyhlásenie Autonómie Slovenska 6. 10. 1938, prehlušil smútok nad smrtou Andreja Hlinku, ktorý zomrel 16. 8. 1938. Pri tejto príležitosti vznikla antológia Requiem za Andreja Hlinku, do ktorej prispelo viacero básnikov a viacero básni bolo publikovaných v dobových časopisoch. Ďalšou smutnou udalostou bola Mníchovská dohoda z 30. 9. 1938. Pre Slovákov bola však najbolestnejšou tzv. Prvá viedenská arbitráž z 2. 11. 1938. Po tejto udalosti už prestali mlčat takmer všetci slovenskí poeti a prostredníctvom smútku premeneného na básnické slovo sa prihlásili noví mladí básnici. Cielom tohto príspevku je poskytnút literárnohistorický prehlad básní a piesní súvisiacich s týmito závažnými udalostami.

V kontexte spomenutých udalostí bolo vyhlásenie Slovenského štátu 14.3.1939 pre našich autorov v istom zmysle zadostučinením. Preto na jar 1939 vzniká z iniciatívy Emila Boleslava Lukáča antológia Pred ohnivým drakom (1939) s podtitulom antológia poézie pohnutých časov. Básnik tu zhromaždil zväčša predtým časopisecky publikované básne širokého spektra slovenských autorov. Poetiku týchto básní bližšie približila Mária Bátorová v svojej monografii Roky úzkosti a vzopätia v kapitole Rok 1938 v slovenskej poézii.

Editor Emil Boleslav Lukáč v doslove píše: „Celý národ bol účastníkom i dejatelom európskych krútňav, ktoré svojimi spodnými prúdmi i prejavmi hrozili mu, azda ešte viacej než iným národom, stroskotaním. A ked'celý národ, nuž akoby ich neboli hlboko prežili, preboleli slovenskí básnici? Bolo by možné, aby ich citlivý duševný seizmograf nereagoval na obrovský svetový súboj ideí, systémov, náhl’adov, civilizačných prúdov? "1 $\mathrm{V}$ závere Lukáč vysvetluje, že viacero básní musel z rozličných

Lukáć, Emil Boleslav, 1939. Doslov. In: Lukáč, Emil Boleslav (ed.): Pred ohnivým drakom. Bratislava: Miestny odbor Matice slovenskej, 120. 
príčin vynechat'. Vyšli totiž i samostatné zbierky, venované smutnému osudu Slovákov. Tým sa bude venovat’ druhá čast̉ môjho príspevku.

K spomenutým historických mílnikom treba ešte doplnit všeobecnú mobilizáciu z 23. 9. 1938, ktorú taktiež zachytili slovenskí básnici. Lukáč antológiu Pred ohnivým drakom rozdelil na 4 časti. Oklieštovanie hraníc Československa a najmä nášho územia je zachytené v tretej časti nazvanej Ortiel' slovenskej zeme a štvrtej časti Volanie o spravodlivost', ktorá vyústuje k básňam pojednávajúcich o vzniku slovenského štátu.

Andrej Žarnov v básni Ortiel nerezignuje, zostáva odhodlaným a odvážnym: „Tisíckrát vstaneme, i ked'dnes padáme / budeme žit' i mriet za tvoju podobu, / na to ti prísahou svoju čest' skladáme!" (“2 Politickým predstavitelom štátu vyčíta pasivitu a podvolenie sa diktátu: „Tá krutá rana páli jedine, pre našu zem a národ $v$ dedine, / že miesto pera zbraň mi nedali, / že cudzí kupci domov predali," v básni Smútok slovenského básnika3. Zložitá situácia nenechala bez reakcie ani lavičiarov. V zborníku nachádzame tiež básnické príspevky Laca Novomeského či Jána Poničana. Azda Najväčšiu krivdu pocitoval Fraňo Král, ktorý veršoval: „Tento rok / červeným černidlom hanby / zaznačte do dejín / Brat zraneného brata zašliapol do blata. “4 Fraňo Král dalej nazýva ospravedlnenia politikov ako „vatu cynických omlúv“.

V Lukáčovom zborníku čítame tiež báseň Slávy Manicovej, mladej poslucháčky Lekárskej fakulty UK, ktorá sa nedávno pripomenula prostredníctvom antológie Potopené duše (2017). Báseň má názov 2. november: „Ach mlč len mlč ty zem poranená / nech nárek dolín stíchne v plač vrchov / Znova vás počut! Tvár vaša pohanená / je vyhňou muky v ohnisku rokov. “5 Poetka sa teda prihovára zabratej zemi, aby sa tá vzoprela a neslúžila novým pánom.

Lukáč z početnej generácie mladých autoriek vybral práve Slávu Manicovú pravdepodobne preto, že bola ako on evanjelického vierovyznania. V dobovej tlači sa však objavili i básne iných poetiek, ktoré v knihe Pred ohnivým drakom absentujú. Napr. báseň Nory Preusovej Odkaz do Šurian z novín Slovák je ladená rovnako ako spomínaná Manicovej báseň 2. november. Preusová hovorí: „Nuž iba takto ku vám vravím / nech d’alej odkaz letí / nech Parom udrie Pánom grófom / Pán nech im nič neposvätí. “6 Silné slová z pera 17-ročnej študentky učitelského ústavu. Ovela pokojnejšie pôsobí báseň vtedy už etablovanej poetky Maši Halamovej Zabranej zemi: „Čas hrobár, do ticha, / zatlika klince minút, / čo vzali máj. / V nemote rozluky / $k$ tebe sa privinút." ${ }^{7}$

I spirituálne ladeného Jána Harantu silne zasiahli spomínané udalosti. V básni November 1938 sa intímne prihovára zabranému územiu: „Máš upluvané skráne, znetvorené líce, / máš tichý asketický úsmev prijatia $i$ vzdoru, / bohatý chodí $k$ tebe žobrat' a hriešny teba lákat', I strom zeme ozýva sa bolestou tvojich stakkát / a brázdu tvoju lakomci závisti pluhom orú. " ${ }^{8}$ Celkom prirodzene $\mathrm{v}$ antológii Lukáč uverejnil i niektoré svoje vlastné básne. Napr. báseň Belvedere (kde bola podpísaná Viedenská arbitráž). Utrpenie Slovákov básnik pripodobňuje Kristovmu utrpeniu: „Tŕňovú

2 Žarnov, Andrej, 1939. Ortiel'. In: Lukáč, Emil Boleslav (ed.): Pred ohnivým drakom. Bratislava: Miestny odbor Matice slovenskej, 59.

3 Žarnov, Andrej, 1939. Smútok slovenského básnika. In: Lukáč, Emil Boleslav (ed.): Pred ohnivým drakom. Bratislava: Miestny odbor Matice slovenskej, 60.

4 Král, Fraňo, 1939. 1938 (Na sever). In: Lukáč, Emil Boleslav (ed.): Pred ohnivým drakom. Bratislava: Miestny odbor Matice slovenskej, 84.

5 Mánicová, Sláva, 1939. 2. november. In: Lukáč, Emil Boleslav (ed.): Pred ohnivým drakom. Bratislava: Miestny odbor Matice slovenskej, 69.

6 Preusová, Nora, 1940. Odkaz do Šurian. In: Slovák. 22/202, 9.

7 Halamová, Maša, 1939. Zabranej zemi. In: Lukáč, Emil Boleslav (ed.): Pred ohnivým drakom. Bratislava: Miestny odbor Matice slovenskej, 105.

8 Haranta, Ján, 1939. November 1938. In: Lukáč, Emil Boleslav (ed.): Pred ohnivým drakom. Bratislava: Miestny odbor Matice slovenskej, 70. 
korunu nám znova vsadili, / a klince tîkli v naše strhlé telá. / Octom nás napájali, kankán tančili, / špongiu výsmechu pot zotierali z tela." ${ }^{\text {"9 }}$

V roku 1938 však muselo Československo tiež odstúpit čast’ severnej Oravy Pol’sku, čo nemohlo ujst básnickému peru Andreja Žarnova, ktorý v básni Pozdrav s iróniou pozdravuje pol’ských romantikov: „Pozdravujem t’a krásne, Mickewicz, / i tebe, Juljusz, drahý brat... / Prečo sme sa len rozíst' museli, / ked” som oboch mal rak rád. “10 Dodajme, že Žarnov patril k popredným prekladatelom polskej poézie už v tomto období, o čom svedčí najmä jeho výberová antológia U polských básnikov. Spor o Oravu rovnako nemohol obíst' Rudolfa Dilonga, rodáka z Trstenej, ktorý v básni Trhajú Oravu hovorí: „že naše bajonety horkost skúsia, až bolest' hladiet' na nás zo strany, že naše pušky ustupovat' musia / a ja som vojak domov poslaný!" ${ }^{11}$ Dilongova odhodlanost' bojovat' sa neskôr prejavila tým, že neskôr, počas druhej svetovej vojny sa dobrovolne sám prihlásil na východný front.

Druhá skupina básnikov sledovala pohnuté osudy národa cez konkrétne bolesti jednotlivcov. Kým predošlí hovorili najmä o zemi, krajine, nasledujúci sa venujú najmä ludským osudom. Napr. František Hečko prostredníctvom básne Bolavý Tekov: „Sŕdc devätdesiat tisíc ešte mocne bije, / bo mŕtve ženy tri si klakli pred dom každý / a krstia krvou živých, aby žili navždy. " ${ }^{2}$ Podobne Pavol Horov, ktorý dovtedy ešte nevydal žiadnu básnickú zbierku uverejňuje báseň s názvom 62-ročný starec bráni hranice, v ktorej ho stvárnil nasledovne: „Do dosák kamenných vykrešte jeho podobu / do dosák kamenných zasadte jeho rysy / pancierom patiny ho zacloňte / aby bol večne živý. "13

Spomedzi všetkých slovenských miest bola pravdepodobne najbolestnejšou strata Košíc. Básnik Vladimír Rolko ich prirovnáva k neveste v básni $Z$ košických verbunkov: „Blízke sú fronty, I rovnaké dvojčatá, / Košice sú čiernou nevestou. " ${ }^{4}$

Zabratie južného územia Slovenska násilne rozdelilo i mnohé rodiny, ktoré sa takto ocitli na územiach dvoch štátov. Táto bolest̉ potom gradovala najmä počas sviatkov rodiny, akými sú vianočné sviatky. Píše o tom napr. Alexander Pockody v básni List matke do Mad’arska: „A ty, mat’ moja, bolas na polnočnej? / Slovenská bola? Či už farár nový? / A teraz sediac v izbičke tej bočnej, / hladíš jak sneží na sad jabloňový?"15

Spomínaná Viedenská arbitráž vel’mi zasiahla básnika Antona Prídavka. Ten vo roku 1940 vydal básnickú zbierku Do videnia!, ktorú venoval „,bratom a sestrám slovenským na odtrhnutom území. Okrem toho na jar 1944 zostavil antológiu Duch a zbraň, podobnú Lukáčovej antológii. Zaradil však do nej i básne autorov, ktorých Lukáč vynechal, napr. Svetloslava Veigla a jeho báseň Bratom v Madiarsku.

Prídavkova zbierka Do videnia! obsahuje 32 básní s touto tematikou. Zdanlivo monotematické básne vyzdvihujú viaceré momenty, ktoré sú povšimnutiahodné. Básne často oscilujú medzi

9 Lukáč, Emil Boleslav, 1939. Belvedere. In: Lukáč, Emil Boleslav (ed.): Pred ohnivým drakom. Bratislava: Miestny odbor Matice slovenskej, 74.

10 Žarnov, Andrej, 1939. Pozdrav. In: Lukáč, Emil Boleslav (ed.): Pred ohnivým drakom. Bratislava: Miestny odbor Matice slovenskej, 79.

11 Dilong, Rudolf, 1939. Trhajú Oravu. In: Lukáč, Emil Boleslav (ed.): Pred ohnivým drakom. Bratislava: Miestny odbor Matice slovenskej, 83.

12 Hečko, František, 1939. Bolavý Tekov. In: Lukáč, Emil Boleslav (ed.): Pred ohnivým drakom. Bratislava: Miestny odbor Matice slovenskej, 81.

13 Horov, Pavol, 1939. 62-ročný starec bráni hranice. In: Lukáč, Emil Boleslav (ed.): Pred ohnivým drakom. Bratislava: Miestny odbor Matice slovenskej, 86.

14 Rolko, Vladimír, 1939. Z košických verbunkov. In: Lukáč, Emil Boleslav (ed.): Pred ohnivým drakom. Bratislava: Miestny odbor Matice slovenskej, 95.

15 Pockody, Alexander, 1939. List matke do Mad’arska. In: Lukáč, Emil Boleslav (ed.): Pred ohnivým drakom. Bratislava: Miestny odbor Matice slovenskej, 108. 
zúfalstvom a povzbudením odtrhnutých bratov. I ked’ je zbierka dedikovaná južným Slovákov, nájdeme tu i básne venované odtrhnutej Orave, napr. básne Bratovi či Javorina. Básne sú v zbierke radené chronologicky, teda od jesene 1938 až po vypuknutie druhej svetovej vojny. V titulnej básni Do videnia autor vyzdvihuje svoje odhodlanie a ako keby povzbudzuje sám seba: „Ja, vojak, sprisahaný na živého Boha, / sa staviam na krvavé hranice / a čakám na rozhodný povel!"16 V stave dezilúzie privoláva dávne i nedávne osobnosti našich dejín. V citovanej básni privoláva Andreja Hlinku: „Ak pohynieme mnohí, vstane z hrobu Hlinka / a desat pokolení vyhrnie sa za ním zo zeme. / V kom viery aspoň omrvinka, / sa pridá $k$ zástupu / a pôjde s nami. "17 V básni Tisíc rokov zasa na pomoc privoláva Svätopluka, v básni Predjarie zasa Jánošíka: „Hej, Juro Jánošík, či strpís bezprávie / a stony rodných počuješ zniet’ v dialave?" ${ }^{18}$ Mimochodom, Prídavok je tiež autorom Drámy Pribina a básnickej zbierky Valaška a dukáty, teda predstavované motívy boli autorovi blízke a venoval sa im systematicky.

Podobne ako Pockody i Prídavok tematizuje prvé Vianoce rozdelenej slovenskej krajiny. V básni sa opät prihovára celkom dôverne: „Vy aspoň jedlu chceli by ste, bratia, však? / čo pod Tatrami o volnosti snívala... "19 Pýta sa, či vôbec Kristus príde do neslobodnej krajiny, ked’ v básni d’alej pokračuje: „Či prišiel ku vám Kristus aspoň mimod’ak? / Ak prišiel, či ho slobodná zem vítala?“20 Báseň prebral i Lukáč do už spomínanej antológie Pred ohnivým drakom. Kedže Anton Prídavok pôsobil v Košiciach na viacerých miestach, napr. ako redaktor rozhlasu, nečudo, že básní hovoriacich o smutnom osude Košíc má v zbierke viacero. V básni nazvanej prosto Košice vzýva patrónku chrámu: „Pomôž nám, patrónka, Alžbeta svätá, / do skazy išli sme, tažká je strašne / za spásu sám ti mericu zlata, / len keby zbavit’ sa bláznivej vášne... "21

Prídavok však vojnu nepovažuje za adekvátne riešenie krivdy spáchanej Slovákom. Jeho odpor voči vojne je citelný. Vyjadruje to v básni Vojna: „Znie koncert besný. Mieru pišu tanky epitaf I a na kopytách konských diabol svety roznáša. / Je kliatba pekiel na storočí tomto zdivelom, / $v$ ňom za škovránka aeroplány tešia oráča. “22 Kedže Prídavkovu staršiu poéziu možno zaradit do kontextu ruralisticky ladenej poézie, sú preto motívy domova a slovenskej zeme časté i týchto jeho angažovaných básňach. Smutnou udalostou bol tzv. incident v Šuranoch na Vianoce 1938, ked' madarskí žandári zastrelili 18-ročnú Máriu Kokošovú. Báseň nazvanú Šperk jej dedikoval Laco Novomeský a tiež Prídavok v predstavovanej zbierke Do videnia!, kde sa k nej takto prihovára: „Aziat sa v krvi kúpe, / Európa, počuješ? / Hlasnejšie sa ozvi Marka, / ked’už svetu žaluješ... "23 O neznámej obeti Šurian tiež hovorí v básni Malý martýr. V jednej z posledných básní zbierky Všetko spät dúfa v spravodlivé povojnové usporiadanie Európy: „Vierou tisícročia verím vo vzkriesenie, I vidím jasne: deň môj vysnený sa bliži. / Celý národ doma bude. V rodnej vlasti. / Záštitu mám v apoštolskom krízii.“24 Dodajme, že autor zomrel 12. 5. 1945.

Ďalším príspevkom k pohnutým udalostiam je zbierka Jozefa M. Brod’anyho (1903 - 1972), úradníka v Žiline. V zbierke Žalujem (pravdepodobne 1939) zachytil udalosti podobne ako Prídavok. V básni Bratom - Poliakom sa stažuje: „Nuž zvoňte zvony / i umieráćik malý. I Zvoňte a hláste svetu / strašnú odvetu. / Hláste Poliakov ukrutnú pýchu, / že Slovákom nedopriali dychu. "

\footnotetext{
Prídavok, Anton, 1940. Do videnia. Do videnia. Bratislava: Rolnícka osveta, 9. c. d., 10 .

Prídavok, Anton, 1940. Predjarie. Do videnia. Bratislava: Rolnícka osveta, 34.

Prídavok, Anton, 1940. Predjarie. Do videnia. Bratislava: Rolnícka osveta, 17.

Ibid.

21 Prídavok, Anton, 1940. Košice. Do videnia. Bratislava: Rol'nícka osveta, 28.

22 Prídavok, Anton, 1940. Vojna. Do videnia. Bratislava: Rol'nícka osveta, 37.

23 Prídavok, Anton, 1940. Mária Kokošová. Do videnia. Bratislava: Rolnícka osveta, 19.

24 Prídavok, Anton, 1940. Všetko spät. Do videnia. Bratislava: Rol'nícka osveta, 40.

25 Brod’any, Jozef, M., 1939?. Bratom - Poliakom. Žalujem... Žilina: vlastný náklad, 13.
} 
V básni Polnočná v Šuranoch i on píše o Márii Kokošovej. Kedže autor v čase publikovania zbierky pôsobil ako železničiarsky úradník (tento motív možno sledovat’ i na obálke), viacero básní je venovaných práve im: Kurič, Hradlár, Výpravca, Balada o železničiarovi, Neplatný lístok atd. Zo všetkých veršov cítit smútok nad dobovými udalostami.

Takmer zabudnutý básnik a textár Lubomír Kupčok je autorom až dvoch básnických zbierok o udalostiach z prelomov rokov 1938 a 1939: Zákopy na juhu a Defilé (obe 1939). Lubomír Kupčok bol predstavitelom tzv. 3. literárnej generácie a prispieval do časopisu Postup a iných literárnych časopisov. Patril do okruhu bratislavskej bohémy. Literárny vedec Ján Sedlák ho označil za najväčšieho bratislavského bohéma, čo konštatoval i Martin Vašš vo svojej nedávnej monografii Bratislavská umelecká bohéma v rokoch 1920 - 1945. Zbierku Zákopy na juhu dedikoval kamarátom z mobilizácie 1938. Básňou nazvanou dátumom 10.11. 1938 reaguje na zabratie územia Petržalky: „ortiel' sa ozaj vyhladit nedá / z národného kréda / zdíhavo / druh druha mrví / druh druha kori “' ${ }^{26}$ Alegorickou básňou Prestrelka na hraniciach zasa reagoval na tých, ktorí sa pokúšali utiect’ z okupovaného územia patriaceho Madarsku na Slovensko. Kupčokova poézia v porovnaní s predošlými básňami je viac založená na expresivite výrazu, básnik využíva gradáciu a básne tiež rozčleňuje typograficky, aby aj ich vonkajšia kompozícia pôsobila chaoticky a nesúrodo. Obdobne komponoval i básne v cykle Defilé, v ktorých vykreslil atmosféru tzv. Malej vojny.

Atmosféra smútku sa okrem predstavenej angažovanej poézie odzrkadlila tiež v tzv. revizionistických piesňach. Doposial' sa mi podarilo vypátrat 4 . Všetky boli vydané v notách v nakladatelstve Jána Stožického v Bratislave, ktorý vydával moderné slovenské šlágre. Azda najznámejšou a v istom zmysle veselou je pochodová pieseň Chceme nazad Košice. Autorom hudby a textu je Ján Pelikán, jeden z trendsetterov modernej slovenskej populárnej hudby z konca 30. rokov. Ústredný motív textu je obdobný spomínanej básni Pavla Horova: „Chceme nazad Košice, $k$ tomu ešte Levice, čo nám vzali. Náš pán richtár hovorili, že šest'desiat rokov má, že by si tiež vystrelili, z poriadneho kanóna... "27 Smutnejší a lyrickejší tón je v piesňach Čo nám vzali, to nám vrátia a Spomienka strateným. Obe sa ponášajú na staršie slovenské hymnické piesne, napr. Kolo Tatier čierňava alebo Kto za pravdu horí. Obe sú komponované v pomalom tempe rubato. Autorom textu piesne Čo nám vzali, to vrátia je Arnold Flögl, Čech, spevák, významný člen opery Slovenského národného divadla. Text piesne chce povzbudit Slovákov v Mad’arsku: „Drahí bratia, čo vás od nás odlúčili, žite duchom, ak ste dosial's nami žili! Hnev utajte v sebe, čo vám v srdciach búri, nad inú zem osud mračien chystá chmúry. “28

Autorom textu tretej piesne, rovnako tahavej je Jarko Elen, textár a dramatik expresionisticky a avantgardne ladených divadelných hier a poviedok, ktoré uverejňoval v Mladom Slovensku. I on povzbudzuje stratených: „Spomienka k Vám za hranice letí, stratení bratia, slovenských hôr. Slobodného národa ste deti, zatnite päste, premôžte bôl! “' ${ }^{(29}$ Poslednou skladbou je tango nazvané Sestrička. Jeho autormi sú bratia Mikuláš a Juraj Koštálovci, ktorí túto pieseň venovali odtrhnutým bratom a sestrám v Madarsku, ako uvádzajú v podtitule skladby. V nej sa prihovárajú nasledovne: „Sestrička, prečo ti srdce zaplače, ked’uzrieš neba slovenského jas. Sestrička noci sa v úsvit premenia, sestrička, dobre s maj, dovidenia. ${ }^{\text {"30 }}$ Toto tango nahral na gramoplatne František Krištof Veselý a predošlé dve tahavé piesne Janko Blaho a Štefan Hoza, významní tenoristi Slovenského národného divadla.

\footnotetext{
Kupčok, Lubomír, 1939. 10. XI. 1938. Zákopy na juhu. Bratislava: vlastný náklad, 10.

Pelikán, Janko, 1939. Chceme nazad Košice. Bratislava: Ján Stožický, 2.

28 Flögl, Arnold, 1939. Čo nám vzali, to nám vrátia. Bratislava: Ján Stožický, 2.

29 Elen, Jarko, 1939. Spomienka strateným. Bratislava: Ján Stožický, 2.

30 Koštál, Juraj, 1939. Sestrička. Bratislava: Ján Stožický, 2.
} 
Vo svojom príspevku som chcel upozornit na básnické príspevky mnohých už dnes zabudnutých autorov, ktorými chceli autentickým spôsobom zachytit svoj smútok nad pohnutými udalostami spred osemdesiatich rokov v rámci svojich možností a kompetencií v rozličných podobách. Tvarové a umelecké parametre predstavovanej tvorby sami autori podriadili ich spoločenskej nevyhnutnosti a naliehavosti. Básne tak majú celkom prirodzene viac historickú než estetickú hodnotu. Jedinečným spôsobom napomáhajú k rekonštrukcii historického kontextu tých čias.

\section{SUMMARY}

A number of well-known and less well-known authors present a great feeling of a contemporary atmosphere throughout the society. Common signs were feelings of abandonment, betrayal, loneliness, curse, and pain. Emil Boleslav Lukáč, as an evangelical priest and theologian, has compiled a representative book in which he has given space to experienced and established authors (Andrej Žarnov, Valentín Beniak, Rudolf Dilong), but also to the beginner and little known author (Pavol Horov, Štefan Žáry, Sláva Manicová). Some were previously known for their agitational and political attitudes (Andrej Žarnov), but some of them with political verses were presented for the first time (Jan Haranta). In the anthology, it is also possible to see the rare concord between Catholics and Evangelicals, as well as between the rule-autonomists (Andrej Žarnov) and the leftwing-predominantly communists (Laco Novomeský, Fraňo Král). The unspoken sphere represents the songs mentioned above, which have found echo among a wide audience. The contribution thus maps a wide sphere of manifestations of the period atmosphere of these important events in the history of Slovakia.

\section{LITERATÚRA}

Brod’any, Jozef, M., 1939?. Žalujem... Žilina: vlastný náklad.

Elen, Jarko, 1939. Spomienka strateným. Bratislava: Ján Stožický.

Flögl, Arnold, 1939. Čo nám vzali, to nám vrátia. Bratislava: Ján Stožický.

Koštál, Juraj, 1939. Sestrička. Bratislava: Ján Stožický.

Kupčok, Lubomír, 1939. Zákopy na juhu. Bratislava: vlastný náklad.

Lukáč, Emil Boleslav (ed.), 1939. Pred ohnivým drakom. Bratislava: Miestny odbor Matice slovenskej.

Pelikán, Janko, 1939. Chceme nazad Košice. Bratislava: Ján Stožický.

Prídavok, Anton, 1940. Do videnia. Bratislava: Rolnícka osveta.

\section{KONTAKT}

Mgr. Peter Tollarovič

Katedra slovenskej literatúry a literárnej vedy

Filozofická fakulta Univerzity Komenského v Bratislave

Gondova 2

81499 Bratislava

Slovenská republika

tollarovic.peter@gmail.com 